in or according to the metric system of weights and measures.

Sec. 6. That rules and regulations for the enforcement of this Act not inconsistent with the provisions hereof shall be made and promulgated by the Secretary of Commerce. The Secretary of Commerce shall also take such steps as he may deem expedient for giving publicity to the dates of transition specified herein and for facilitating the transition to the meter-liter-gram or metric system.

Sec. \%. That all Acts or parts of Acts inconsistent herewith are hereby repealed but only in so far as they are inconsistent herewith; otherwise they shall remain and continue in full force and effect. Whenever in any Act, or rules and regulations, or tariff or schedule made, ratified, approved, or revised by the Government of the United States of America weights or measures of the system now in customary use are employed or referred to, and to comply with the provisions of this Act weights and measures of the metric system should be employed, then such references in such Act, rules and regulations, tariff, or schedule shall be understood and construed as references to equivalent weights or measures of the metric system ascertained in accordance with the required degree of accuracy.

Sec. 8. That nothing in this Act shall be understood or construed as applying to-

(1) Any contract made before the date at which the provisions of this Act take effect;

(2) The construction or use in the arts, manufacture, or industry of any specification or drawing, tool, machine, or ather appliance or implement designed, constructed, or graduated in any desired system;

(3) Goods, wares, or merchandise intended for sale in any foreign country, but if such goods, wares, or merchandise are eventually sold for domestic use or consumption then this clause shall not exempt them from the application of any of the provisions of this Act.

Sec. 9. That nothing herein shall be understood or construed as prohibiting the enactment or enforcement of weights and measures laws or ordinances by the various States or cities, and the various States or cities shall have the same powers as though this Act were not in force and effect: Provided, however, That no standard weights or measures shall be established for the uses set out herein which conflict in any way with the standards established herein, and such standards which may already have been established shall be null and void for the uses set out herein.
Sec. 10. That the word "person" as used in this Act shall be construed to import both the plural and singular, as the case demands, and shall include corporations, companies, societies, and associations. When construing and enforcing the provisions of this Act, the act, omission, or failure of any officer, agent, or ather person acting for or employed by any corporation, company, society, or association, within the scope of his employment or office, shall in every case be also deemed to the act, omission, or failure of such corporation, company, society, or association as well as that of the person.

After discussion, the bill was referred to the Committee on Weights, Measures, and Coinage of the Academy for report, with power to act through the President of the Academy. Upon receipt of the report from the Chairman of that Committee, Dr. Thomas C. Mendenhall, the following communication was sent to Senator Ladd:

December 1, 1921

My. dear Senator Ladd: Referring again to my recent communications regarding bill $\mathrm{S} 2267$ to fix the Metric System of Weights and Measures as the single standard for certain uses, I have received a report from the Committee on Weights, Measures, and Coinage, which was authorized to act for the National Academy of Sciences, approving bill S2267 with the following statement:

" Any measure that might now be passed is tolerably certain to need modification and amendment before the end of the probationary period."

Very truly yours,

$$
\begin{aligned}
& \text { (Signed) Charles D. WalcoTt, } \\
& \text { President }
\end{aligned}
$$

As Senator Ladd has requested that publicity be given to this action of the Academy, I am sending you this statement for inclusion in SCIENCE.

$$
\begin{aligned}
& \text { Charles D. WalcotT, } \\
& \text { President }
\end{aligned}
$$

\section{STAINS FOR THE MYCELIUM OF MOLDS AND OTHER FUNGI}

To the Editor of Scinnce: Microscopic examinations to determine the extent to which the mycelium of various fungi has penetrated infected specimens of wood consume an unduly large amount of time. Methods using organic substances, dyes and stains, to obtain a differ- 
ential coloring that will make mycelium stand out in contast to the tissue of the host have been described. ${ }^{1}$

The writers, in an attempt to obtain a stain which would reduce the time required for the examinations of a set of woods infected with molds by producing satisfactory differentiation both for visual examination and for photomicrography, have worked out the following method. The results, although the work is only in the preliminary stage, are so promising that they are given here in order that others may avail themselves of the method if they desire to do so.

Since there is a difference in chemical composition between wood substance and chitin or "fungous cellulose," the assumption was made that the fungous mycelium might possess characteristic mildly oxidizing or reducing properties. Then a solution of silver nitrate in distilled water was applied to thin sections of the infected wood. These were allowed to stand for periods of various lengths, overnight staining giving a very satisfactory result. The sections were then examined directly or dehydrated with alcohol, cleared with xylol, and mounted in Canada balsam. Drying the balsam mounts under weights in an oven over night appeared, if anything, to improve the stain secured.

Both conifers and hardwoods were treated in this way. The mycelium of several molds and of two wood-destroying fungi has thus far been stained. In all cases the mycelium was differentiated by its blackish brown, purplish brown, or orange color. The wood tissue presented, if stained, a lighter shade of yellowish brown against which the mycelium was readily visible, often under relatively low magnifications.

Silver nitrate solution also gave interesting staining of the wood structures and cell contents which will be discussed at some future time.

Gold chloride solution, and the "Berlin Blue" stain, the latter as described by Dr. Sophia Eckerson in her course in microchem-

1 Sinnott, E. W. and I. W. Bailey, Phytopath., 4: 403, 1914. Vaughan, R. E., Ann. Mo. Bot. Gard., $5: 241,1914$ and others. istry, ${ }^{2}$ were also used with some success for the same purposes as the silver nitrate.

M. E. Diemer,
Chemist,
Eloise Gerry,
Microscopist
Forest Products Laboratory,
U. S. DePartment OF Agriculture,
Madison, Wisconsin

\section{SHARKS AT SAN DIEGO}

To the Euitor of Science: It has occurred to the writer that a very brief statement of some experiences in collecting shark material at San Diego, Cal., in 1920-21 might be of value to persons interested in research problems in elasmobranch morphology and embryology. Owing to the fact that the reduction plants in San Diego paid in 1920-21 a price for sharks high enough to make it worth while for the fishermen to bring in all such material caught incidentally, and since nearly all such material was brought to the fishmarket pier, at the latter place it was possible in a very short time to collect a considerable range of species. The writer obtained twentysix species of elasmobranchs at San Diego, and the embryos of fourteen of them. No other place along the Pacific coast, or probably on any other coast, offers such a wealth of material and such easy access to it. It was not uncommon to see fifteen species of elasmobranchs at one time on the pier at San Diego.

H. W. NoRRIS

\section{GrinNell College}

\section{MUNICIPAL OBSERVATORIES}

To the Editor of Science: In Solence for August 5, the Municipal Observatory at Des Moines is "said to be the only municipal observatory in the world." The Cincinnati Observatory was incorporated in 1842, its corner stone being laid in 1843 by John Quincy Adams. Here Cleveland Abbe (director '68-'73) first issued daily weather reports and laid the foundation of the U. S. Weather Bureau. In 1872, the property was transferred to the University of Cincinnati (municipal) on condition that the city sup-

2 Text-book now in preparation. 